
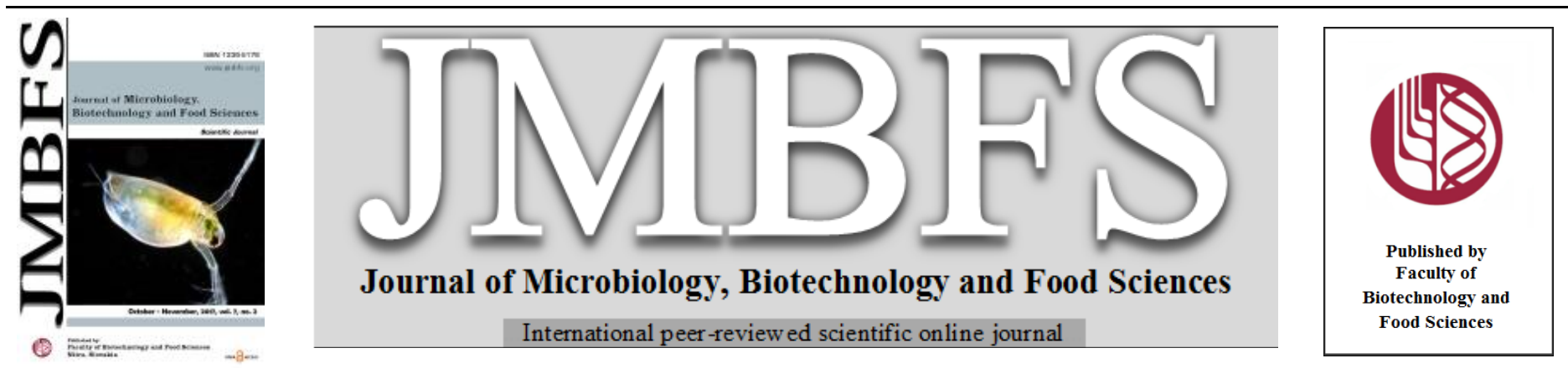

\title{
EFFECT AND MECHANISM OF ACTION OF NON-THERMAL PLASMA IN THE SURVIVAL OF Escherichia coli, Staphylococcus aureus AND Saccharomyces cerevisiae
}

\author{
Solis-Pacheco J.R ${ }^{l}$, Aguilar-Uscanga B.R ${ }^{l}$, Villanueva-Tiburcio J.E ${ }^{l}$, Macias-Rodríguez M.E ${ }^{l}$, Viveros-Paredes J.M ${ }^{l}$, González- \\ Reynoso $O^{l}$ and Peña-Eguiluz $R^{2}$
}

\begin{abstract}
Address(es):
${ }^{1}$ Centro Universitario de Ciencias Exactas e Ingeniería. Universidad de Guadalajara, Jalisco, México. Boulevard Marcelino García Barragán \#1421, Col. Olímpica. Guadalajara, Jalisco C.P. 44430 México. Tel: 13785900 ext: 27525

${ }^{2}$ ININ- Instituto Nacional de Investigaciones Nucleares, Laboratorio de Física de Plasmas. Carretera México-Toluca s/n, La Marquesa, Ocoyoacac, C.P. 52750 México. Tel. +52(55) 53297200 .

*Corresponding author: josuesolisp@gmail.com

doi: 10.15414/jmbfs.2017.7.2.137-142

\section{ARTICLE INFO}

Received 6. 10. 2016

Revised 14. 6. 2017

Accepted 7. 9. 2017

Published 1. 10. 2017

Regular article

OPEN ${ }_{\text {ACCESS }}$

ABSTRACT

Non-thermal plasma (NTP) is an emerging technology of great interest because the elimination of pathogens and spoilage microorganisms and their probable use in various industrial sectors such as food and health. In this study was to evaluate the inactivation of non-thermal plasma on the survival of Escherichia coli ATCC 25922, Staphylococcus aureus ATCC 51811 and Saccharomyces cerevisiae. Treatments of different microorganisms were conducted with cells exposed NTP generated dielectric barrier reactor (DBD) able to produce atmospheric pressure plasmas. These devices operate at $13.56 \mathrm{MHz}$ and are driven by a specifically built radio frequency (RF) resonant converter. The reactors, which operate at atmospheric pressure in a He-air gas mixture at a $1.5 \mathrm{~L} \mathrm{~min}^{-1}$ flow rate, applying a $850 \mathrm{~V}$ voltage at different exposure times $(10,20,40,60,80,100$ and $120 \mathrm{~s})$. All the strains showed a reduction in viability of $<0.001 \log \mathrm{CFU} \mathrm{mL}{ }^{-1}$ after to exposed to plasma. The cells showed membrane damage, these effects being the main cause for microbial inactivation, caused by the action of Non-thermal plasma, which leads to membrane and/or cell wall breakdown with consecutive DNA denaturation, these being the main factors inducing microorganism death.
\end{abstract}

Keywords: Non-thermal plasma, DNA damage, cell wall, membrane, microorganisms, food safety

\section{INTRODUCTION}

The non-thermal plasma is an emerging technology that is drawing attention in different sectors of process such as food (Bermúdez et al., 2013; Yong, H. I. et al. 2015) and health (Fridman, G. et al. 2008), for the removal of microorganisms that degrades substrate, causing diseases and economic losses for the industry; in this sense, the control and elimination is an important challenge (Van Houdt 2010; Skandamis 2012). The impact of modern technologies leading to the production of minimally processed foods, both safe and of nutritional quality after the process is relevant to the food industry (Floros 2010). That is why in recent years new technologies have been developed to replace physical methods characterized by using heat as a primary mode to inactivate or kill microorganisms (Knorr 2011).

In physical sciences, "plasma" refers to the forth state of matter. The plasma permits a flux of various active uncharged species of atoms and molecules as well as UV. These active uncharged species generated in plasma will typically include ozone $\left(\mathrm{O}_{3}\right)$, NO, OH radicals, etc. These charges may consist of both electrons as well as positive and negative ions. specifications permit the disinfection or sterilization of thermosensitive materials and allow in vivo applications, opening a new and larger spectrum of possible applications. The first devices developed have already proven their bactericidal properties in vitro, ex vivo, and in vivo (Klämpfl et al. 2012). Akishev et al. (2008) worked on Atmospheric Pressure Cold Plasma APCP/ NTP sterilization and they studied Escherichia coli and Serratia marcenses, classified as prokaryote Gram (-) bacteria as well as Gram (+) bacteria Bacillus subtilis. They also studied the eukaryotic fungi Candida lypolitica and Aspergillus niger. They explain that the elucidation of the most probable inactivation mechanisms is dependent on several considerations: 1) NTP active agents $\left(\mathrm{O}, \mathrm{OH}, \mathrm{O}_{3}\right)$ are not obstructed in their action on any one particular cell by other cells present in the colony; 2) cell damage is due to active plasma agents inflicting chemical injury on cell structure; 3) damage to one cell implies no lethal consequences, but amassed injury may inactivate the cell at the time of NTP or later on; 4) mathematical analysis describing NTP microorganism inactivation points to cell wall and membrane disruption by NTP leading to DNA and cell content destruction; and finally 5) gas pressure plays a crucial role in total cell inactivation.
The effectiveness of non-thermal plasma to eliminate different pathogens has been studied by Perni (2008), who used non-thermal plasma decontamination on mango (Mangifera indica) peels and melon (Cucumis melo L) shells, reducing 3 $\log$ CFUcm ${ }^{-2}$ Pantoea agglomerans and Gluconoacetobacter liquefaciensstrains after $2.5 \mathrm{~s}$ of treatment, while to eliminate Escherichia coli, it was necessary to apply plasma treatment for $5 \mathrm{~s}$; for Saccharomyces cerevisiae, treatment was longer (10 and $30 \mathrm{~s}$ for its inactivation on mango peel and melon shell, respectively).

Niemira and Sites (2008) studied inactivation of Salmonella and Escherichia coli O157: $\mathrm{H} 7$ in Golden apples and oranges. They inoculated $100 \mu \mathrm{L}\left(\sim 10^{8}\right.$ $\mathrm{CFU})$ Escherichia coli on the surface of the apples and Salmonella on orange surfaces, observing that a 3 min treatment with plasma reduces the Salmonella population from 3.7 to $2.9 \log \mathrm{CFU} \mathrm{mL} \mathrm{m}^{-1}$ and from 3.6 to $3.4 \log \mathrm{CFU} \mathrm{mL} \mathrm{m}^{-1}$ for Escherichia coli O157:H7. Similarly, Gallagher et al. (2007) investigated the effect of non-thermal plasma on air decontamination, obtaining up to $5 \mathrm{Log} \mathrm{mL}^{-1}$ reduction of Escherichia coli (strain K-12). A similar result was obtained by Vaze et al. (2010) who observed up to a $5 \mathrm{Log} \mathrm{mL}^{-1}$ reduction of Escherichia coli in an air flow after $10 \mathrm{sec}$ of exposure to plasma.

Other researchers, Dobrynin et al. (2010) subjected Bacillus cereus and Bacillus anthracis to a non-thermal plasma treatment, observing $5 \mathrm{Log} \mathrm{mL}^{-1}$ inactivation of these strains after a 1 min treatment. Moissan et al. (2011) made theoretical references about the action mechanisms of microorganism-killing non-thermal plasma. They postulated that non-thermal plasma may cause damage to the membrane and cell wall, with consequent damage to DNA caused by UV light and the free radicals generated by the interaction of plasma with ambient air at the time of exposition. Dobrynin et al. (2011) demonstrated that there was a transport of charged molecules into the cell, such as hydrogen peroxide $(\mathrm{OH}-$ $\left(\mathrm{H}_{2} \mathrm{O}\right) \mathrm{n}$ and $\left.\mathrm{H}_{3} \mathrm{O}^{+}\left(\mathrm{H}_{2} \mathrm{O}\right) \mathrm{n}\right)$ and that the efficiency of these radicals to promote microorganism death is much greater than free ions, such as $\mathrm{O}_{3}, \mathrm{~N}_{3}$ and argon ions.

Although microorganism decontamination caused by NTP exists There are studies that suppose the mechanism of destruction of the cell. For this reason, the aim of this study was to evaluate the effect of non-thermal plasma on the viability of Escherichia coli ATCC 25922, Staphylococcus aureus ATCC 51811 and 
Saccharomyces cerevisiae and, furthermore to determine the mode of action of plasma on these organisms, analyzing cell wall damage and DNA denaturation.

\section{MATERIAL AND METHODS}

\section{Microorganisms}

The strains of Escherichia coli ATCC 25922 (FDA strain Seattle 1946, American Type Culture Collection, E.U), Staphylococcus aureus ATCC 51811 (BioCyc Database Collection, Menlo Park, California. E.U), and Saccharomyces cerevisiae CTSA (a strain isolated from must of tequila and characterized for genus and species by molecular biology), were lyophilized and kept at $-80{ }^{\circ} \mathrm{C}$ for preservation.

\section{Dielectric barrier discharge reactor}

The system made up by the radio frequency generator (RF) and the dielectric barrier discharge reactor (RDBD) was designed and built in the Laboratory of Plasma Physics from the National Institute of Nuclear Research, Mexico. The reactor consists of a pair of horizontal stainless steel circular parallel electrodes, $80 \mathrm{~mm}$ in diameter and 2 to $5 \mathrm{~mm}$ spacing regulated. The electrode below is fixed to the lower lid of the reactor by a shaft, while the upper one, in order to fix the gap, can be adjusted by means of a precision screw coupled to a similar shaft attached to the upper lid, the last is constituted by a tubular shaft allowing gas admission. The entire structure is insulated by means of a Pyrex ${ }^{\circledR} 200 \mathrm{~mm}$ long cylindrical structure with a $120 \mathrm{~mm}$ internal diameter (see figure 1). A Petri dish, containing a bacterial colony, is placed between both electrodes, acting as a dielectric barrier. The specially designed $13.56 \mathrm{MHz}$ RF generator directly supplies the reactor parallel plates, applying a $30 \mathrm{~W}$ input power and an output voltage of 850 volts with He-air mixture 1.5 LPM flow. The power in the system can be adjusted with a resolution in the order of milliwatts, as it has been designed to conduct studies on the characterization and interactions of active species and UV radiation from discharges with the microorganisms.

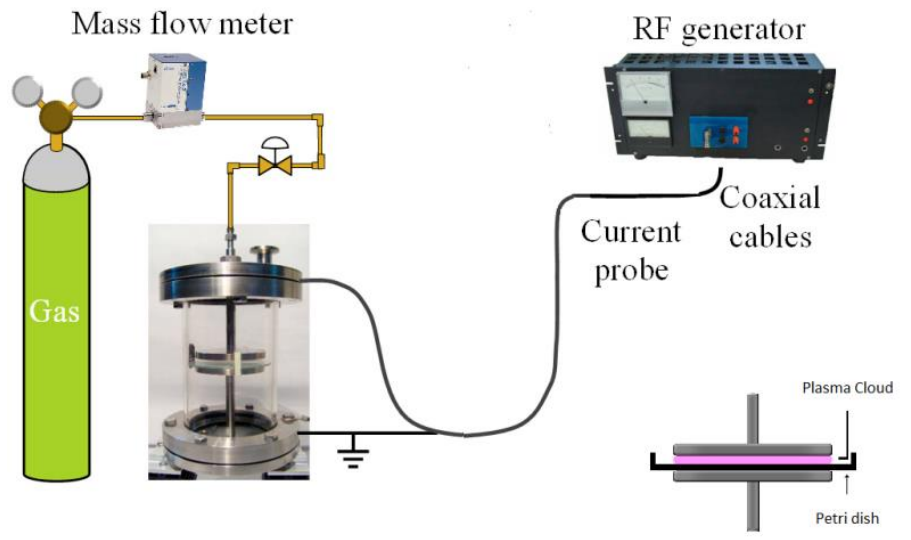

Figure 1 Experimental setup diagram implemented for the generation of plasma discharges

\section{Microorganism culture}

Prior to treatment with plasma, growth was achieved in the bacteria E. coli ATCC 25922 and $S$. aureus ATCC 51811 in nutrient broth (BD Bioxon) at $35^{\circ} \mathrm{C}$ for $24 \mathrm{~h}$ (MAI TERLAB Model 60, HINOTEK, China), and for S. cerevisiae yeast cultivation, liquid medium YPD was used (yeast extract and casein peptone $5 \mathrm{~g} / \mathrm{L}$ dextrose $20 \mathrm{~g} / \mathrm{L}$ ) incubated at $30^{\circ} \mathrm{C}$ for $24 \mathrm{~h}$. Subsequently, the cultures were centrifuged (Hermlez 300K, LabSource, France) at $3500 \mathrm{rpm}$ for $5 \mathrm{~min}$. The supernatant was removed and the biomasses washed with $1 \mathrm{~mL}$ saline, then centrifuged again; subsequently, three washes were performed with consecutive centrifugations at $3500 \mathrm{rpm}$ for $5 \mathrm{~min}$. Absorbance was then measured by spectrophotometer at $625 \mathrm{~nm}$ (Genesis 20, Thermo Spectronic, USA) and the

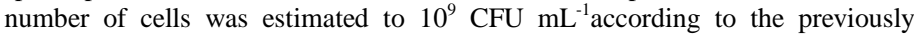
constructed $0.5 \mathrm{McF}$ arland curve for conducting plasma treatment.

\section{Microorganism exposure to NTP}

On $1 \mathrm{~cm}^{2}$ sterile filter paper (Whatman No.1), $20 \mu \mathrm{L}$ of just one cell culture of Escherichia coli ATCC 25922, Staphylococcus aureus ATCC 51811 and Saccharomyces cerevisiae were placed at concentrations of $10^{9} \mathrm{UFCmL}^{-1}$ according to the $0.5 \mathrm{McFarland}$ scale. All samples, excepting one negative control, were subjected to non-thermal plasma exposure for 10, 20, 40, 60, 80, 100 , and $120 \mathrm{~s}$. After that, samples were placed in sterile tubes containing $9.9 \mathrm{ml}$ $0.1 \%$ peptone water, stirred a few minutes on a Vortex (Vortex-Genie 2 mixers,
Scientific Industries, Inc. USA) then decimal dilutions were made. Reseeding for each sample was promptly carried out with the plaque emptying method, using 1 $\mathrm{ml}$ of the dilution. For Escherichia coli ATCC 25922 and Staphylococcus aureus ATCC 51811, nutrient agar was used, incubating the petri dishes at $35{ }^{\circ} \mathrm{C}$ for 24 to $48 \mathrm{~h}$; for Saccharomyces cerevisiae CTSA, potato dextrose agar (PDA) was used and incubated at $28^{\circ} \mathrm{C}$ for 24 to $48 \mathrm{~h}$; finally, colony counting was performed (CRAFT $®$ colony counter, Interscience, France). The mean was calculated and expressed as $\mathrm{CFUmL}^{-1}$ (colony-forming unit per $\mathrm{ml}$ sample).

\section{Qualitative assessment of damage to the wall of the cell membrane.}

The technique described by Klotz et al. (2010) was employed to assess the damage to the membrane and cell wall of the bacteria Staphylococcus aureus ATCC 51811, Escherichia coli ATCC 25922 and Saccharomyces cerevisiae CTSA. This technique is based on interaction with propidium iodide doublestranded DNA. Samples of cell suspensions of Escherichia coli ATCC 25922 and Staphylococcus aureus in phosphate buffer saline solution were prepared at an $0.2 \mathrm{OD}_{680}$ (spectrophotometer model Genesis 20, Thermo Spectronic, USA) corresponding to a concentration of $\sim 2.4 \times 10^{2} \mathrm{CFUmL}^{-1}$, this population density providing the optimum resolution for cell observation in the microscope. Twenty $\mu \mathrm{L}$ of the suspension of each strain were placed on sterile glass slides, and then the slides were exposed to plasma for $10,20,40,60,80,100$ and $120 \mathrm{~s}$. Subsequently, $5 \mu \mathrm{L}$ propidium iodide were added (MP Biomedicals, USA) at a concentration of $1 \mathrm{mg} / \mathrm{mL}$. Then, $10 \mu \mathrm{L}$ methylene blue dye was added (EMB Bioxon) at a concentration of $15 \mathrm{mg} / \mathrm{mL}$ (adding methylene blue was performed in order to neutralize the fluorescence which originates by contact with propidium iodide cells walls of yeasts, giving false positive reading) and dried for 5 minutes. All treated samples were incubated in the dark $\left(22 \pm 1^{\circ} \mathrm{C} / 20 \mathrm{~min}\right)$ and microbial cells were observed with the aid of a fluorescence microscope (Olympus CKX41, USA) at $480 \mathrm{~nm}$ using 40X magnifying lens. From observations, an increase of cell fluorescence was noticed, indicating microorganism membrane or cell wall rupture.

\section{DNA extraction and analysis by agarose gel electrophoresis}

For assessing DNA damage, $100 \mu \mathrm{L}$ microorganism cells $\left(\sim 2.4 \times 10^{2} \mathrm{CFUmL}^{-1}\right)$ were placed on a sterile glass slide. Each set of seven slides were exposed to plasma for 10, 20, 40, 60, 80, 100, and $120 \mathrm{~s}$. After treatment a DNA extraction was carried out on Escherichia coli ATCC 25922 and Staphylococcus aureus ATCC 51811 using the genomic DNA extraction kit (Promega). The total DNA of Saccharomyces cerevisiae CTSA was carried out with the Rapid Yeas Genomic DNA Extraction Kit BS8227-50P (Bio Basic Canada Inc). In order to analyze DNA fractions, a gel of $0.7 \%$ agarose plus $1 X$ SYBR safe (Invitrogen) in TAE buffer (Tris/acetate/EDTA), was charged with the same amount of DNA extracts $(2 \mu \mathrm{g})$ and subjected to electrophoresis for $1 \mathrm{~h}$ at $75 \mathrm{~V}$. Gel image was documented with a EZ Gel Doc (Bio Rad, USA). As positive control, a sample of DNA treated with a restriction enzyme (EcoRI) was included in the gel previously described.

\section{Statistical analysis}

The present study was conducted 3 independent trails (replicates). Statistical analysis was performed using Statgraphics Centurion XV V15.2.06 (StatPoint, Inc., USA). The microbiological assessment data were subjected to an analysis of variance (ANOVA), and the mean values were compared using Fisher's least significant difference (LSD) at a level of 0.05 .

\section{RESULTS AND DISCUSSION}

\section{Death kinetics in microorganisms and decimal reduction value,}

The results of microbial death kinetics are shown in Figures $2 a, 2 b$ and $2 c$ (survival curves). When comparing the inactivation kinetics of plasma, differences in microbial reduction levels were found. A critical parameter for evaluating the efficiency of a microbial reduction technology is the decimal reduction D value (Klotz 2010; Pflug 2000). This value is a time required to inactivate $90 \%$ of the microbial population, and was calculated taking the negative inverse of the slope from the linear equation for each phase of microbial death, as expressed in the following equation:

$D=1 / m$

where:

$\boldsymbol{D}$ is the time (in minutes) required to inactivate $90 \%$ of the microbial population and $\boldsymbol{m}$ is the slope of the linear equation for each phase of microbial death 


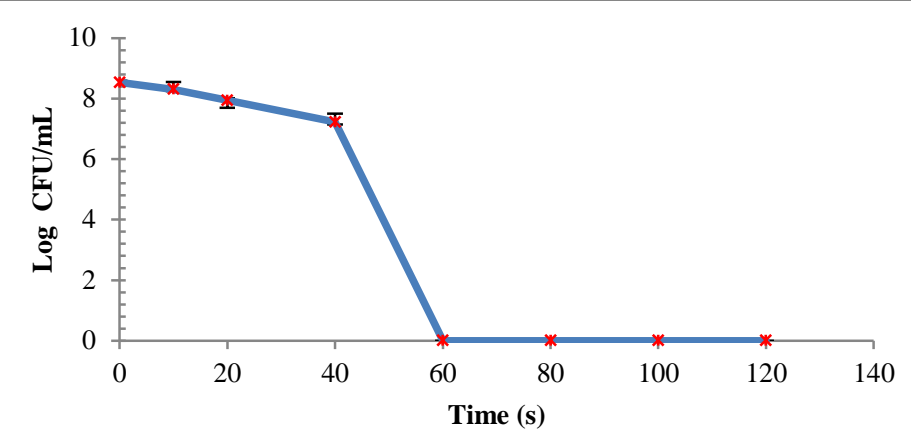

(a)

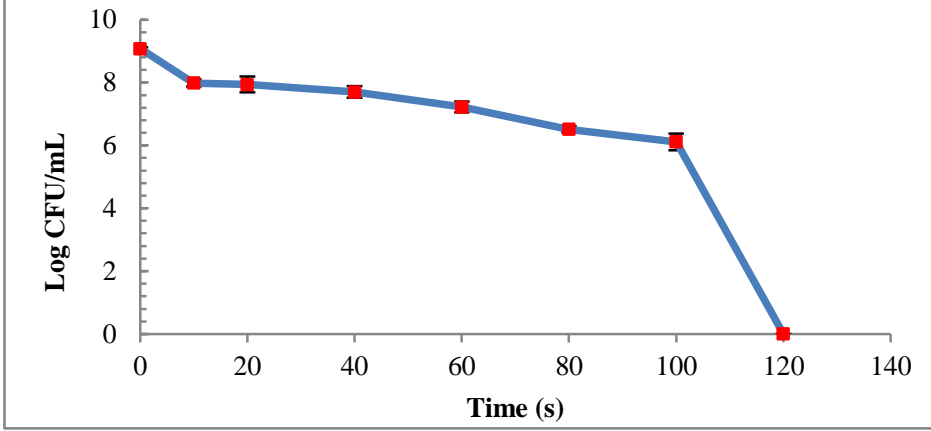

(b)

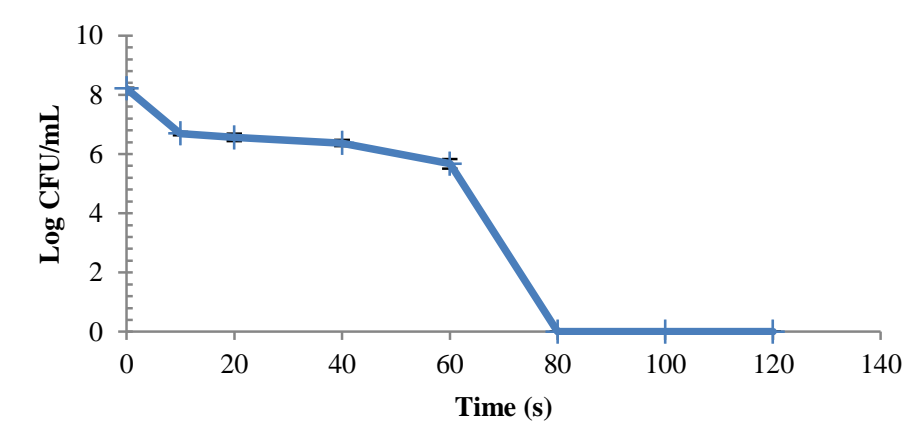

(c)

Figure 2 Kinetics of microorganism death when exposed to non-thermal plasma (850 V) for 120 s. a) Escherichia coli ATCC 25922, b) Staphylococcus aureus ATCC 51811, c) Saccharomyces cerevisiae CTSA

After exposure of different microorganism strain to plasma, it was observed that inactivation kinetics of Escherichia coli ATCC 25922 (Figure 2a) showed a biphasic behavior $(\mathrm{p}<0.05)$ where, two calculating the decimal reduction in each of the slopes of the biphasic function, it can be observed a significant reduction (Table 1). We observed following $60 \mathrm{~s}$ of plasma exposure, a rapid reduction of microbial population, where E.coli was inactivated. In the case of Staphylococcus aureus ATCC 51811 (Figure 2b), microbial inactivation was observed from 120 of cold plasma treatment. Three phases of microbial reduction were observed with significant differences $(\mathrm{p}<0.05)$ with logarithmic jumps 9.2, 45.2 and 3.4 seconds respectively for each slope. As in $E$. coli, $S$. aureus show a total elimination of microbial load after 2 minutes, initial concentration being reduced $\log 9.07 \pm 0.18 \mathrm{CFU} \mathrm{ml}^{-1}$ to $<\log 0.001 \mathrm{CFU} \mathrm{ml} \mathrm{H}^{-1}$. On exposure to NTP of the yeast Saccharomyces cerevisiae CTSA also presented three slopes microbial reduction with statistically significant differences $(\mathrm{p}<0.05)$ (Table 1$)$

Table $1 \mathrm{D}$ Values (decimal reduction) in microorganisms exposed to cold plasma at 850 Volts

\begin{tabular}{|c|c|c|c|}
\hline \multirow[b]{2}{*}{ D Values ${ }^{1}$} & \multicolumn{3}{|c|}{ Microorganisms } \\
\hline & $\begin{array}{c}\text { Escherichia coli } \\
\text { ATCC } 25922\end{array}$ & $\begin{array}{c}\text { Staphylococcus } \\
\text { aureus ATCC } \\
51811\end{array}$ & $\begin{array}{c}\text { Saccharomyces } \\
\text { cerevisiae CTSA }\end{array}$ \\
\hline D1 & $30.08^{a, \S} \pm 8.31$ & $9.22^{\mathrm{a}, \uparrow} \pm 1.23$ & $6.56^{\mathrm{a}, \dagger} \pm 0.19$ \\
\hline D2 & $2,79^{\mathrm{b}, \S} \pm 0.10$ & $45.26^{\mathrm{b}, \dagger} \pm 1.64$ & $51.02^{\mathrm{b}, \dagger} \pm 7,06$ \\
\hline D3 & ------ & $3.54^{\mathrm{c}, \dagger} \pm 0.56$ & $\begin{array}{c}3,54^{\mathrm{c},{ }^{\dagger}} \pm 0.1 \\
0\end{array}$ \\
\hline
\end{tabular}

${ }^{1} \mathrm{D}$ values (in seconds) correspond to the average $\pm S \mathrm{D}, \mathrm{n}=3$

The letters $\mathrm{a}, \mathrm{b}, \mathrm{c}$, represent statistical differences of $\mathrm{D}$ values within each

microorganism.

Symbols $\S$ and $\dagger$ represent statistical differences between $\mathrm{D}$ values compared between

different microorganisms.
The significant reduction in yeast concentration occurred in the time 60 to $80 \mathrm{~s}$ of treatment with a $\mathrm{D}=51.02$ seconds (Figure 2C); after $80 \mathrm{~s}$ treatment, a reduction of up to $8.21 \pm 0.18<0.001 \log \mathrm{CFU} \mathrm{ml^{-1 }}$ was obtained. S. aureus was more resistant to NTP treatment with 120 seconds for complete removal. Compared with $E$. coli being $50 \%$ higher and for $S$. cerevisiae $33.3 \%$, respectively (Figures $2 \mathrm{a}, \mathrm{b}, \mathrm{c})$. The reducing the concentration of microorganisms is evident after $60 \mathrm{~s}$ of treatment. The obtained time of inactivation and D are different and these results are genus and species dependent. For instance, the microbial inactivation kinetics of $S$. aureus and $S$. cerevisiae showed three inactivation phases and three D values, while $E$. coli had only two death phases. The fact that $S$. aureus had a higher D value than did E. coli suggests that peptidoglycans function as a physical shield against plasma. This was also observed with $S$. cerevisiae, the cell wall structures of which differ from those of bacteria and are more difficult to rupture mechanically. Thus, the reactive species produced by NTP interaction with ambient air, have greater difficulty breaking the cell wall or membrane of Gram-positive bacteria and yeasts than of Gram-negative bacteria. According to the results of the death kinetics of the three microorganisms, we think that the first microorganism death phase could be caused by the formation of free radicals, which interact on the components of cell walls, while in the second phase; the action of free radicals would be of greater intensity as it would be on weakened cell walls. Laroussi (2002) describes that during microbial death kinetics, several phases occur and explain that the first phase (D1) is produced by the action of UV light, the second phase (D2) is attributed to a process erosion by the active species (free radicals), and in the third phase (D3) the UV light acts by damaging the genetic material of microorganisms. Nevertheless, Georgescu $\boldsymbol{e}$ al.(2010) details the inactivation of microorganisms because of NTP can be due to the charged particles, electric fields, UV photons and some reactive species such as atomic oxygen, metastable oxygen molecules, ozone and hydroxyl radicals, which are commonly found in a gas discharge. In particular, when helium is used as the main gas and starts to be in contact with air some of the generated species are oxygen atoms, $\mathrm{OH}$ radicals, nitrogen atoms, NO radicals, nitrogen ions, etc.

We could associate also this phenomenon to peroxidation lipid and polysaccharide which cause bacterial inactivation (Dobrynin et al. 2009). We believe that the difference between the compositions of the cell walls of these microorganisms is the cause of the different inactivation behaviors among $E$. coli, $S$. aureus and $S$. cerevisiae, the damage of NTP may depend on the thickness of the cell wall. For example E.coli (Gram-negative) present a thin layer of peptidoglycan, located between two layers of phospholipids, which are attached to an outer membrane through a lipoprotein, whereas Gram-positive bacteria such as Staphylococcus aureus have a thick layer of peptidoglycan, teichoic acids and two kinds of lipoteichoic acid (Kubista, 2006; Tortora, 2012). On the other hand, in yeast, three main groups of polysaccharides form their cell wall: $40 \%$ mannoproteins, $60 \% \beta$-glucan and $2-5 \%$ of chitin (Klis et al. 2006).

\section{Damage to the cell wall}

The damage of the cell wall is determined qualitatively, where the results of Escherichia coli ATCC 25922, Staphylococcus aureus ATCC 51811 and Saccharomyces cerevisiae were treated with NTP and are shown in Figure 3. From 10 and $20 \mathrm{~s}$, it began to observe an orange colored and stronger fluorescence was obtained at $60 \mathrm{~s}$ of treatment for all microorganisms. It is evident that with increasing time of treatment with NTP causes the breakdown of the cell wall in bacteria and yeast for the release for internal cellular material where there are DNA in the case of prokaryotic and eukaryotic. The propidium iodide have contact with the freed genetic material of the microorganism causing the fluorescence and depending of the genetic concentration material of its intensity (Figure 3). 

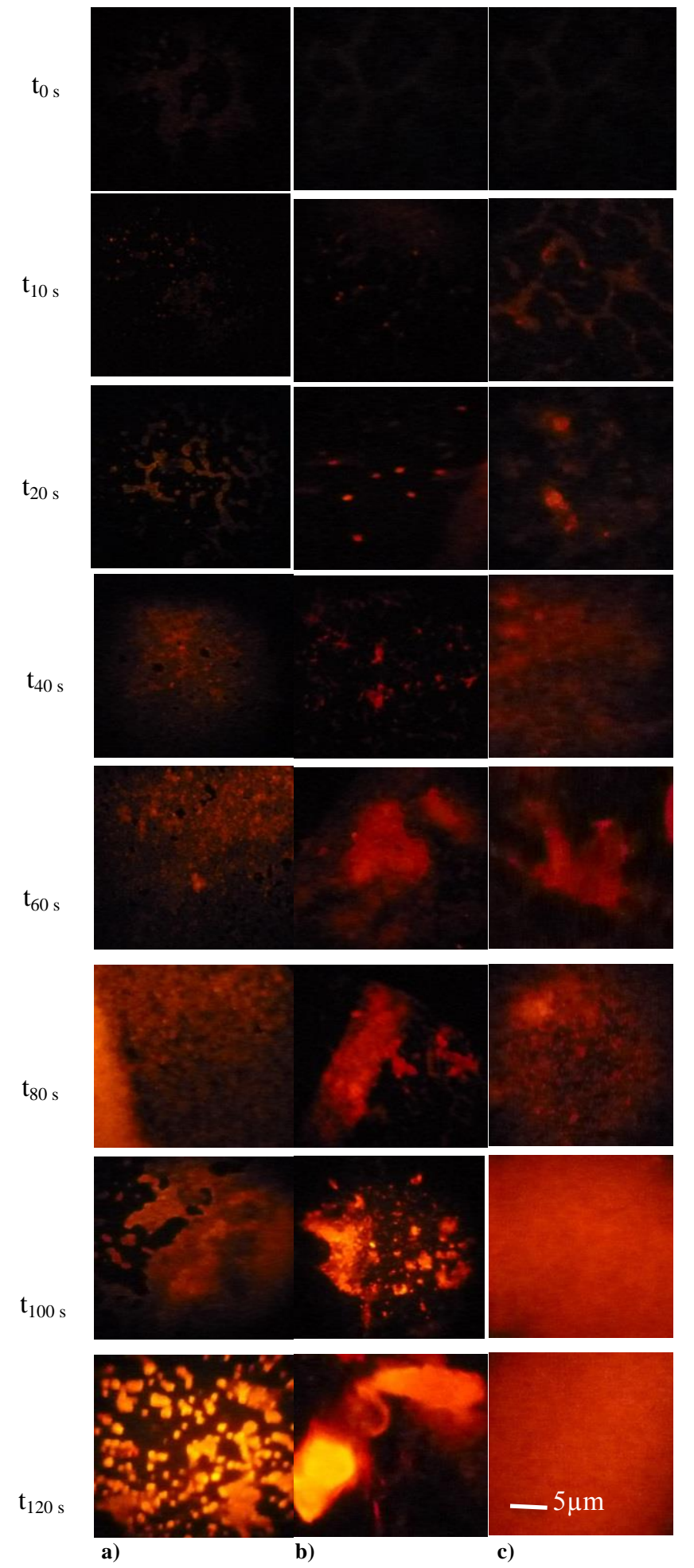

Figure 3 Propidium iodide fluorescence $(1 \mathrm{mg} / \mathrm{ml})$. a) Escherichia coli ATCC 25922, b) Staphylococcus aureus ATCC 51817 and c) Saccharomyces cerevisiae CTSA, exposed to non-thermal plasma at different times. Degree of magnification (400X).

It can be noted, that cell walls suffered lysis with increased plasma treatment time (Figure 3). We assumed that the increase in fluorescence was directly related with the interaction of propidium iodide with the yeast nucleic acids after lysis. It has been shown that in the case of bacteria, the combined effect of the magnetic field and free radicals provoke the electroporation phenomenon (Azharonok, 2009; Dobrynin, 2011), breaking the cell walls and causing the release of genetic material with a probable degradation of DNA. E. coli ATCC 25922, S. cerevisiae CTSA and S. aureus ATCC 51811 treated with NTP show an increase in fluorescence intensity in function of treatment time after 10, 20 and $40 \mathrm{~s}$ respectively, indicating that there is an increase in the interaction of DNA with interact propidium iodide, (Van Frankenhuyzen, 2011). This would indicate that as treatment times of treatment in different microorganisms, causes an increase of lysis in the cell wall that leads them to death. However, Gadri et al. (2000), reported that even the similar D value of Gram-positive and Gram-negative exposed to non-thermal plasma, in Gram-negative bacteria lysis and fragmentation occurred in the cell wall, but in Gram-positive bacteria this did not happen.

\section{Microorganism DNA analysis in agarose gel}

The technique of agarose gel electrophoresis was implemented with the aim of evaluate the effect on the DNA after the application of NTP at different times. Figure 4 shows the agarose gel electrophoresis of DNA obtained from the three different microorganisms, showing the integrity of DNA, interpreting the results as previously done by Ryuet al.(2013) for a treatment with NTP of S. cerevisiae AH109. Regarding Escherichia coli ATCC 25922, at $60 \mathrm{~s}$ we observed that treatment with NTP (lanes 1 to 5) do not cause an observable damage to the DNA. However, after $80 \mathrm{~s}$ treatment (lane 6) the DNA band which represents the intact DNA disappears. Similarly, the integrity of the DNA of $S$. aureus ATCC 51811 and S. cerevisiaes showed signs of degradation until $120 \mathrm{~s}$ of treatment with NTP, in both cases it could be observable the presence of a DNA as an intact band.

a)

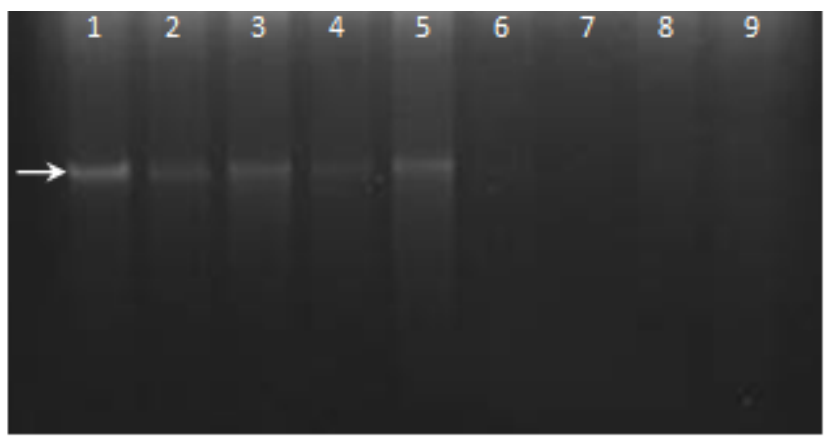

b)

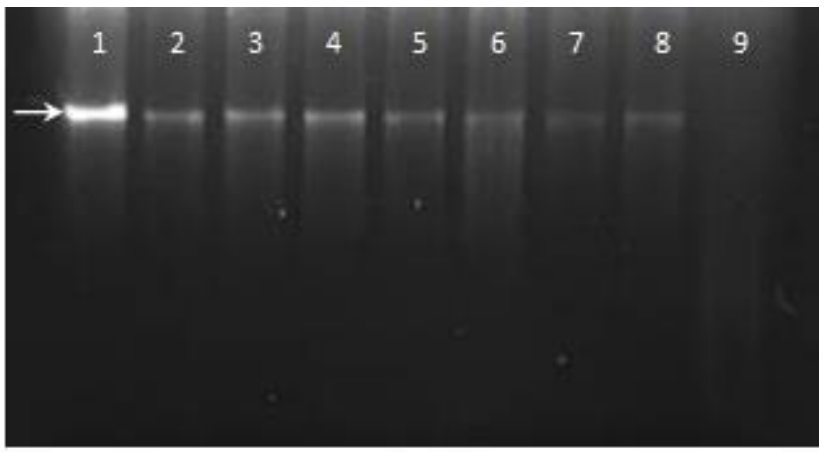

c)

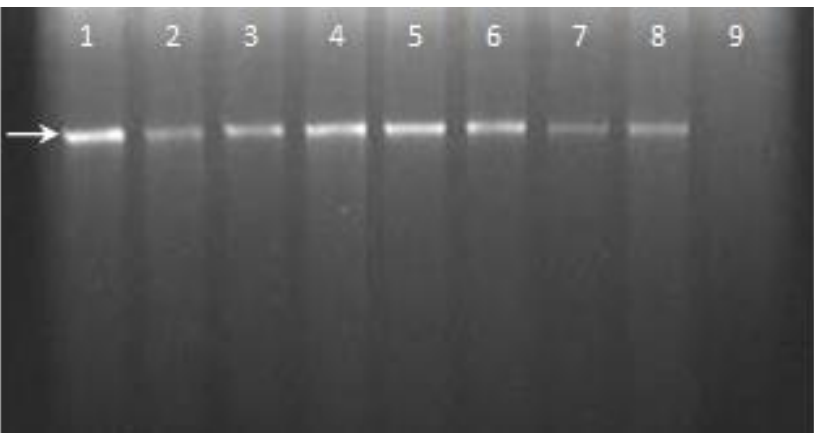

Figure 4 Kinetics of degradation DNA in microorganisms exposed to nonthermal generated with helium gas. a) Escherichia coli ATCC 25922, b) Staphylococcus aureus ATCC 51811, c) Saccharomyces cerevisiae CTSA. Lane 1) $0 \mathrm{~s}$, 2) $10 \mathrm{~s}$, 3) $20 \mathrm{~s}$, 4) $40 \mathrm{~s}$, 5) $60 \mathrm{~s}$, 6) $80 \mathrm{~s}$, 7) $100 \mathrm{~s}$, 8) $120 \mathrm{~s}$ 9) DNA control (denatured DNA with enzyme restriction EcoRI). Terms of run: 0.7\% agarose, 75 volts and $37 \mathrm{~mA}$. Run time: $1 \mathrm{~h}$. Note: The horizontal arrows indicate DNA bands of the microorganisms treated with non-thermal plasma.

In the case of DNA degradation, Escherichia coli ATCC 25922 was the microorganism that suffered more fragmentation of DNA at a lower time $(60 \mathrm{~s})$ on (Figure 4a); however, for S. aureus ATCC 51811 and S. cerevisiae CTSA, there was not DNA fragmentation observed after of $120 \mathrm{~s}$ of treatment (Figures 4b, c). According to Tortora et al. (2012), the cell wall of Gram-positive bacteria contains a thicker layer of peptidoglycan with respect to Gram-negative bacteria Since they are composed of a peptidoglycan layer, the cell wall of $E$. coli ATCC 25922 (Gram-negative) probably suffered lysis in less time than S. aureus ATCC 51811 (Figures 3a, b), and as a consequence, E. coli ATCC 25922 DNA 
fragmentation was higher than that of $S$. aureus ATCC 51811 (Figures 4a and b), and as a consequence, $E$. coli ATCC 25922 DNA fragmentation was faster than the $S$. aureus ATCC 51811. Another important aspect in the case of prokaryotic bacteria is that DNA is in free form in the cytoplasm (Kubista, 2006), a feature that favors DNA interaction with NTP constituents and its interaction with ambient air, such as free radicals, UV light, charged particles (Pflug, 2000) Evidence exists that low-energy electrons cause damage to DNA (Gadri, 2000); additionally, UV light causes photodimerization in adenine (Alizadeh, 2011).

The DNA of Saccharomyces cerevisiae CTSA does not show any fragmentation (Figure 4c) demonstrating that $S$. cerevisiae CTSA cell wall consists of glucans, mannoproteins, and chitin, making it more resistant to cell wall rupture than the case of Gram-negative bacteria (E. coli ATCC 25922), as is noted in the increase of fluorescence (the experiments with the propidium iodide technique). However, $S$. aureus ATCC 51811 was more resistant than $S$. cerevisiae CTSA, perhaps because of its thick peptidoglycan layer. Another aspect about the yeast $S$. cerevisiae CTSA is that it is a eukaryote and has a membrane that protects its nuclear DNA against free radicals, UV light and charged particles generated by NTP. It probably obstructs plasma in penetrating to the core and destroying DNA in yeast, while prokaryotes (bacteria) do not have this membrane (Kubista 2006)

Rastogi et al. (2010) submitted viral DNA samples extracted from E. coli cells and bovine serum albumin (BSA) to ultraviolet radiation exposition. The results showed that viral DNA suffered degradation from $10 \mathrm{~s}$ on, and after $20 \mathrm{~s}$ of treatment, DNA was completely degraded. The research by Morales-Ramírez $\boldsymbol{e}$ al. (2013), who submitted mouse leukocytes to exposure to RF non-therma needle plasma at different distances $(0.1$ and $0.5 \mathrm{~cm}$ from the tip of needle to samples), obtained complete DNA fragmentation at $0.1 \mathrm{~cm}$. However, the presence of proteins around DNA molecules can protect them from the effects of plasma generated reactive species $\left(\mathrm{NO}, \mathrm{HO}^{*}, \mathrm{O}_{3}, \mathrm{O}_{2}\right)$ and thereby reduce damage (Morales-Ramirez, et al. 2013)

Finally, Dobrynin et al. (2009) analyzed the interaction of floating electrode dielectric barrier discharge (FE-DBD) in living tissues and cells. They discussed and presented the biological action (reactant species ROS) and physical mechanisms in the tissues and cells. They proposed three major hypotheses for the results observed: 1) ROS metabolism is different in prokaryotic (bacteria) and eukaryotic (mammalian) cells, e.g. while human cells have protection from $\mathrm{O}_{2}$ bacteria either lack it completely or their resistance is lower. 2) higher order organisms have developed more resistance mechanisms to external stress (osmotic pressure changes, ROS, chemical and biological poisons, etc.), in other words, bacteria usually act as a single cell while mammalian cells, especially those organized into tissues, communicate with each other possibly lowering the effects of the applied poison; finally, 3) bacterial cells are usually much smaller than mammalian cells and thus have much higher surface to volume ratio, therefore simply a lower dose of poison is required to inactivate the same number of bacteria as opposed to mammalian cells. They stated that although their result are potentially promising, many unanswered questions and gaps in understanding remain and that selectivity is still an open question where deeper understanding is needed about the mechanism of interaction of plasma with bacterial and parasite cells.

\section{CONCLUSION}

The action of non-thermal plasma and its active components on microorganisms Escherichia coli ATCC 25922, Staphylococcus aureus ATCC 51811 and Saccharomyces cerevisiae CTSA caused their cell death during exposure to NTP. This induces breakdown of the microorganism cell walls, despite differences in their constitution, in E. coli cause the release of the genetic material (DNA) and its subsequent degradation. However, S.aureus. ATCC 51811 and Saccharomyces cerevisiae CTSA the release of this material was not gotten out With this study we have shown that microorganism cell wall is the main organelle on which the cold plasma energy acts. Therefore this death process mechanism consists of the action of reactant species or oxidants produced by the NTP which cause breakdown in the cell wall eventually leading to microorganism death.

Acknowledgments: We thank the National Council of Science and Technology of Mexico (CONACyT) for the financial support for the development of this research work and the critical reading of Patricia M. Hayward-Jones M Sc. and Dulce Ma. Barradas-Dermitz, M Sc.

\section{REFERENCES}

Akishev, Y., Grushin, M., Karalnik, V., Trushkin, N., Kholodenko, V., Chugunov, V., Kobzev, E., Zhirkova, Nadezhda., Irkhina, I., and Kireev, G.(2008). Atmospheric-pressure, nonthermal plasma sterilization of microorganisms in liquids and on surfaces. Pure and Applied. Chemistry, 80 (9), 1951-1969. https://doi.org/10.1351/pac200880091953
Alizadeh, E. and Sanche, L. (2011). Measurements of G values for DNA damage induced by low-energy electrons. The Journal of Physical Chemistry B, 115 14852-14858. dx.doi.org/10.1021/jp207922n

Azharonok, V.V., Krat'ko, L.E., Nekrashevich, Y.I., Filatova, I.I., Mel'nikova, L.A., Dudchik, N.V., Yanetskaya, S.A. and Bologac, M.K. (2009). Bactericidal action of the plasma of high-frequencycapacity and barrier discharge on microorganisms. Journal of Engineering Physics and Thermophysics, 82, 419426. doi:10.1007/s10891-009-0210-0.

Bermúdez-Aguirre, D., Wemlinger, E., Pedrow, P., Barbosa-Cánovas, G. \& Garcia-Perez, M. (2013). Effect of atmospheric pressure cold plasma (APCP) on the inactivation of Escherichia coli in fresh produce. Food Control. 34, 149-157. http://dx.doi.org/10.1016/j.foodcont.2013.04.022

Dobrynin, D., Fridman, G., Friedman, G., and Fridman, A. (2009). Physical and biological mechanisms of direct plasma interaction with living tissue. New Journal of Physics, 11(11): 115020. DOI:10.1088/1367-2630/11/11/115020

Dobrynin, D., Fridman, G., Mukhin, Y.V., Wynosky-Dolfi, M.A., Rieger, J., Rest, R.F., Gutsol, A.F. and Fridman, A. (2010). Cold plasma inactivation of Bacillus cereus and Bacillus anthracis (Anthrax) spores. IEEE Transactions on Plasma Sciences,38, 1878-1884. DOI: 10.1109/TPS.2010.2041938

Dbrynin, D., Fridman, G., Fridman, A. and Starikovskiy, A. (2011). Inactivation of bacteria using de corona discharge: role of ions and humidity. New Journal of Physics, 13, 1-16. DOI: 10.1088/1367-2630/13/10/103033

Fridman, G. et al. Applied Plasma Medicine (2008). Plasma Processes and Polymers. 5, 503-533. DOI: 10.1002/ppap.200700154.

Floros, J.D., Newsome, R., Fisher, W. Barbosa-Cánovas, G.V., Chen, H., Dunne, C.P., German, J.B., Hall, R.L. et al. (2010). Feeding the world today and tomorrow: The importance of food science and technology. An IFT Scientific Review, 9, 572-599. DOI: 10.1111/j.1541-4337.2010.00127.x

Gadri B.R., Roth, J.R., Montie, T.C., Kelly-Wintenberg, K., Tsai, P.P.Y., Helfritch, Feldman, P., Sherman, D.M. et al. (2000). Sterilization and plasma processing of room temperature surfaces with a one atmosphere uniform glow discharge plasma (OAUGDP). Surface and Coatings Technology, 131, 528-542. http://dx.doi.org/10.1016/S0257-8972(00)00803-3

Gallagher, Jr.M.J., Vaze, N., Gangoli, Sh., Vasilets, V.N., Gutsol A.F., Milovanova, T.N., Anandan, Sh., Murasko, D.M. and Fridman A.A. 2007. Rapid inactivation of airborne bacteria using atmospheric pressure dielectric barrier grating discharge. IEEE Trans Plasma Sci. 35(5):1501 - 1510. DOI: 10.1021/es203770q

Georgescu, N., Lungu, C. P., \& Lupu, A. (2010). Chemical activation of the high voltage pulsed cold atmospheric plasma jets. Romanian Reports in Physics, 62(1), 142-151

Klämpfl, T. G., Isbary, G., Shimizu, T., Li, Y.-F., Zimmermann, J. L., Stolz, W., Schlegel, J., et al. (2012). Cold atmospheric air plasma sterilization against spores and other microorganisms of clinical interest. Applied and environmental microbiology, 78(15), 5077-82. doi:10.1128/AEM.00583-12

Klis, F.M.; Boorsma, A. and De Groot, P.W.J. (2006). Cell wall construction in Saccharomyces cerevisiae. Yeast, 23, 185-202. DOI

10.1002/yea.1349

Klotz, B., Mañas, P. and Mackey, B.M. (2010). The relationship between membrane damage, release of protein and loss of viability in Escherichia coli exposed to high hydrostatic pressure. International Journal of Food Microbiology, 137, 214-220. DOI: 10.1016/j.ijfoodmicro.2009.11.020

Knorr, D., Froehling, a., Jaeger, H., Reineke, K., Schlueter, O. and Schoessler, K. (2011). Emerging technologies in food processing. Annual Review of Food Science and Technology, 2, 203-235. DOI: 10.1146/annurev.food.102308.124129 Kubista, M., Andrade, J.M., Bengtsson, M., Forootan, A., Jonák, J., Lind, K., Sindelka, R., Sjöback, R., et al. (2006). The real-time polymerase chain reaction. Molecular Aspects of Medicine, 27, 95-125. DOI:10.1016/j.mam.2005.12.007. Laroussi, M. (2002). Nonthermal decontamination of biological media by atmospheric-pressure plasmas: Review, analysis and prospects. IEEE Transactions on Plasma Sciences, 30, 1409-1415. DOI: 10.1109/TPS.2002.804220.

M. Moisan, J. Barbeau, S. Moreau, J. Pelletier, M. Tabrizian, L'H. Yahia, (2001) Low-temperature sterilization using gas plasmas: a review the experiments and an analysis of the inactivation mechanisms, International Journal of Pharmaceutics 226, 1-21. http://dx.doi.org/10.1016/S0378-5173(01)00752-9.of Morales-Ramírez, P., Cruz-Vallejo, V., Peña-Eguiluz, R., López-Callejas, R., Rodríguez-Méndez, B.G., Valencia-Alvarado, R., Mercado-Cabrera, A. and Muñoz-Castro, A.E. (2013). Assessing cellular DNA damage from a helium plasma needle. Radiation Research, 179, 669-673. DOI:10.1667/RR3223.1.

Niemira, B. and Sites, J. (2008) Cold plasma inactivates Salmonella Stanley and Escherichia coli O157: H7 inoculated on golden delicious apples. Journal Food Protection, 71, 1357-1365. DOI: 10.1146/annurev-food-022811-101132.

Perni, S., Liu, D.W., Shama, G. and Kong, M. (2008). Cold atmospheric plasma decontamination of the pericarps of fruit. Journal Food Protrection, 71, 302-308. http://dx.doi.org/10.4315/0362-028X-71.2.302

Pflug, I.J., and Gould, G.W. (2000). Heat Treatment. In: The Microbiological Safety and Quality of Food ed. Lund M.B., Baird-Parker T.C. and Gould, G.W pp 38-41. United States of America. 
Rastogi, R.P., Richa, Kumar, A., Tyagi, M.B. and Sinha, R.P. (2010). Molecular mechanisms of ultraviolet radiation-induced DNA damage and repair. Journal of Nucleic Acids, 1-32. DOI:10.4061/2010/592980.

Ryu, Y. H. Yong-Hee Kim, Jin-Young Lee, Gun-Bo Shim, Han-Sup Uhm, Gyungsoon Park, Eun Ha Choi.(2013). Effects of Background Fluid on the Efficiency of Inactivating Yeast with Non-Thermal Atmospheric Pressure Plasma. PLoS ONE 8, 1-9. DOI: 10.1371/journal.pone.0066231

Skandamis, P.N., Nychas, G.J.E. (2012). Quorum sensing in the context of food microbiology. Applied Environment Microbiology, 78, 5473-5482. DOI: 10.1128/AEM.00468-12

Tortora, G.J., Funke, B.R. and Case, Ch.L. (2012). Microbiology: An Introduction. pp 75-106. Pearson Higher USA.

Van Frankenhuyzen, J.K., Trevors, J.T., Lee, H., Flemming, C.A. and Habash, M.B. (2011). Molecular pathogen detection in biosolids with a focus on quantitative PCR using propidium monoazide for viable cell enumeration. Journal Microbiology Methods, 87, 263-272. DOI:10.1016/j.mimet.2011.09.007 Van Houdt, R., Michiels, C.W. (2010). Biofilm formation and the food industry, a focus on the bacterial outer surface. Journal Applied Microbiology, 109, $1117-$ 1131. DOI:10.1111/j.1365-2672.2010.04756.x.

Vaze, N.D., Gallagher, M.J., Park, S., Fridman, G. Vasilets, V.N. and Gutsol, A.F. (2010). Inactivation of bacteria in flight by direct exposure to nonthermal plasma. IEEE Transactions on Plasma Sciences, 38, 3234-3240. DOI: 10.1109/TPS.2010.2072788

Yong, H. I. et al. (2015). Evaluation of pathogen inactivation on sliced cheese induced by encapsulated atmospheric pressure dielectric barrier discharge $\begin{array}{llll}\text { plasma. } & \text { Food } & \text { Microbiology. } & \text { 46, }\end{array}$ http://dx.doi.org/10.1016/j.fm.2014.07.010. 